\title{
Joanna Ślósarska Uniwersytet tódzki \\ Hermeneutyka śladu i świadectwa w pismach ks. Romana E. Rogowskiego jako projekt egzystencji
}

Są w górach szczyty o takich ścianach, że jeżeli wejdzie się na nie do pewnej wysokości, pozostaje tylko jedna droga - do góry. Zejście i wszelkie trawersy są niemożliwe.

R. E. Rogowski

Sygnaturą bardzo bogatego dorobku piśmienniczego ks. Romana E. Rogowskiego ${ }^{2}$, profesora teologii dogmatycznej i podróżnika, jest temat drogi i wędrówki, stanowiący zarazem utrwalony $w$ tradycji topos religijny i kulturowy. Według niego, „podróż i wędrowanie, droga i pielgrzymka stanowią najbardziej archaiczny i powszechny symbol życia, egzystencji ludzkiej, są obrazem przemijania i dochodzenia do kresu"3. Ujęcie owego archaicznego symbolu życia w jego pismach przyjmuje formę teologii codzienności, budowanej na przeżyciach i doświadczeniach bezpośrednich oraz stałej rekonstrukcji treści kultury w kontekście perykop biblijnych. „Nowe przymierze - pisze Rogowski - konstytuuje teologię drogi i wędrowania jako ludzkiego

${ }^{1}$ R. E. Rogowski, Szukając tego, co zginęło, Opole 1996, s. 185. Por. analogiczną myśl w: tenże, Mistyka gór, Wrocław 1992, s. 115.

${ }^{2}$ W dalszych uwagach odwołuję się bezpośrednio do następujących książek ks. R. E. Rogowskiego: Bóg na moich drogach (Katowice 1986); Tarasy światła (Wrocław 1999); Niewidomy spod Jerycha zadaje pytania. Z księdzem Romanem E. Rogowskim rozmawia Barbara Juśkiewicz (Wrocław 2003); Zamieniłeś $w$ taniec mój żałosny lament (Opole 1999); Pielgrzymując do bram raju (Opole 2003); Wicher i myśl (Katowice 1999); Spostrzegać Go pośród miasta (Częstochowa 2006); Być w sercu świata. Człowiek, teologia i góry (Wrocław 2005); Ogień i słowo (Katowice 2005); Piszac na piasku (Opole 1996); Pielgrzymi morza. Medytacje morskie (Opole 1996); Mistyka Tatr (Kraków 20 o2); Teologia jako sztuka życia (red. ks. R. E. Rogowski, ks. A. Małachowski, Wrocław 2008).

${ }^{3}$ R. E. Rogowski, Bóg na moich drogach..., s. 5. 
losu"4. W książce Pielgrzymując do bram raju autor zamieścił taką dedykację: „Dedykuję Tym, z którymi pielgrzymuję do bram raju - czyli Wszystkim". Uniwersalizując swojego odbiorcę, R. E. Rogowski stawia zarazem owym Wszystkim pielgrzymom konkretne wymagania co do sposobu podróży (jako formy „integralnej aktywności”s) oraz refleksji nad jej przebiegiem.

\section{Podróż w kulturze i w wyobraźni}

Wiążę myśli w tratwę.

R. E. Rogowski ${ }^{6}$

„Lękam się ludzi - pisze Rogowski - którzy przeczytali tylko jedną książkę, poznali tylko jeden kraj i jedli chleb tylko z jednego pieca. Mogą być ciaśni jak szczelina w skale, mogą być skostniali jak skorupa małży. I mogą nie umieć żyć, a i umierać też nie potrafią!"7. W swoich rozważaniach autor Tarasów światła przywołuje więc ogromną liczbę twórców kultury - teologów, filozofów, antropologów, poetów, prozaików, dramatopisarzy, malarzy, rzeźbiarzy, reżyserów, kompozytorów ${ }^{8}$.

${ }^{4}$ R. E. Rogowski, Tarasy światła..., s. 247. Teologię codzienności łączy autor z teologią egzystencjalną, jako sztuką życia, ujmując teologię nie tylko jako orthodoksis, ale także orthopraksis. Zob. tenże, Teologia i życie, [w:] Teologia jako sztuka..., s. 7-16.

${ }_{5}$ „Aktywność winna obejmować całego człowieka - zarówno jego ciało, jak i jego ducha. Dopiero aktywność integralna rozwija go, pogłębia, czyni bardziej człowiekiem" (R. E. Rogowski, Mistyka gór..., s. 172).

${ }^{6}$ R. E. Rogowski, Bóg na moich drogach..., s. 176.

7 R. E. Rogowski, Zamieniłeś $w$ taniec..., s. 135. Słowa te wypowiada Yetino, śnieżny człowiek, imaginowana postać, która napomina i poucza narratora, powołując się na mądrość biblijną. W podobnej funkcji pojawia się dobry anioł Tatranek, postać przywoływana w Mistyce Tatr.

${ }^{8}$ Oto drobny, w stosunku do pełnej listy odwołań, ale oddający różnorodność kontekstów, zbiór nazwisk pojawiających się w pismach Rogowskiego: Arystoteles, Pitagoras, Konfucjusz, Lao-Tsy, Orygenes, św. Jan od Krzyża, Jan Paweł II, Hans Urs von Balthasar, Jakob Böhme, Angelus Silesius, Dietrich Bonhoeffer, Edyta Stein, Karl Barth, Emanuel Léuinas, Umberto Eco, Paul Tillich, Paul Eudokimow, Martin Heidegger, Martin Buber, Mircea Eliade, Thomas Carlyle, Mistrz Eckhart, św. Augustyn, Sören A. Kierkegaard, Grzegorz z Nyssy, Simone Weil, św. Tomasz, Tomasz Merton, Gaston Bachelard, Tomasz Morus, Teilhard de Chardin, Romano Cornuto, Milarepa, William 
Obok odwołań do dzieł konkretnych autorów (wprowadzanych najczęściej jako perykopy literackie $w$ formie krótkich cytatów lub opisów czy spostrzeżeń) pojawiają się także w pismach R. E. Rogowskiego liczne, bardziej ogólne komentarze do politeistycznych i monoteistycznych tradycji kulturowych i religii, ukształtowanych $w$ różnych kręgach etnicznych, m.in. do buddyzmu, hinduizmu, dżinizmu, taoizmu, islamu. Uzasadnieniem wprowadzania rozległych kontekstów ${ }^{9}$, stanowiących składniki metaforycznej tratwy myśli, jest wyrażane wprost przez teologa przeświadczenie o ich istotności dla rozumienia każdego, pojedynczego tekstu życia, kształtującego się wobec różnorodnych, nie zawsze jasno uświadamianych wpływów, współstanowiących jednak synergiczną całość zdarzeń i losów konkretnych ludzi, wspólnot etnicznych, duchowych i wyobrażeniowych. Podróżując przez uniwersum przekazów artystycznych, naukowych i cywilizacyjnych, R. E. Rogowski ustanawia określony tryb ich lektury i interpretacji $w$ stałej perspektywie teologii chrześcijańskiej, przywoływanej najczęściej również $w$ formie konkretnych perykop biblijnych. Jest to projekt szlaku podróżnika, który szuka świadectw. Uczestniczymy $w$ hermeneutycznym dyskursie śladu zderzanego ze świadectwem. Pierwsza z tych kategorii wnosi ideę inwencyjnego odwołania do tradycji, jej pomnażania i przekazywania, wynajdywania nowych znaczeń, określających jakość doświadczenia egzystencjalnego ${ }^{10}$. Natomiast kategorię „świadectwa”

Blake, Omar Chajjam, Walt Whitman, Paul Claudel, Albert Camus, Henry Vaughan, Józef Conrad-Korzeniowski, Gilbert Keith Chesterton, Bernard Shaw, Juliusz Słowacki, John Donne, William Szekspir, George Herbert, Maurice Maeterlinck, Thomas Eliot, Saint-John Perse, William Golding, John Milton, Cyprian Kamil Norwid, Krzysztof Kamil Baczyński, Anna Achmatowa, Marina Cwietajewa, Rafael Alberti, Alejo Carpentier, Julien Green, Fiodor Dostojewski, Jan Kasprowicz, Walter Ralegh, Astrid Lindgren, Ernest Hemingway, Iwan Wazow, Antoine de Saint-Exupéry, Borys Pasternak, Kenneth Hutchin, Jean Cocteau, Julio Cortazar, Rabindranath Tagore, Stanisław Wyspiański, Emily Dickinson, Graham Green, Nikos Kazantzakis, Jorge Luis Borges.

9 Poetyka tekstu i kontekstu $w$ ujęciu R. E. Rogowskiego dotyczy w równym stopniu tradycji religijnej i kulturowej, egzystencji i wyobraźni, ale także kontekstu przelotnych zdarzeń czy słów. Jak pisze: „Tekst życia wyrasta z jego kontekstu. Kontekst jest wszystkim. MAŁA TEOLOGIA zajmuje się kontekstem. Tym, co z pozoru małe, dalekie i niewidzialne. Tym, co $w$ rzeczywistości decyduje o naszym dniu powszednim. Decyduje o życiu” (R. E. Rogowski, Szukajac tego..., s. 10o). „Rzeczy małe decydują o dużych. Sprawy przelotne mają wpływ na sprawy wielkie i trwałe" (R. E. Rogowski, Zamieniłeś $w$ taniec..., s. 14.

1o Por. A. Zawadzki, Hermeneutyka śladu i hermeneutyka świadectwa, [w:] Nowoczesność jako doświadczenie, red. R. Nycz, A. Zeidler-Janiszewska, Kraków 2006 , s. 334. 
(przy całej jej złożoności na gruncie hermeneutycznej polaryzacji stanowisk) możemy najprościej określić jako „przejście z planu tego, co zobaczone, na plan tego, co powiedziane i opowiedziane"11. Podstawową funkcję mediacji między śladem a świadectwem, także między przedmiotem a jego wyobrażeniem, spełnia myślenie symboliczne. R. E. Rogowski, nawiązując do Mircei Eliadego, pisze, iż myślenie symboliczne jest

[...] konsubstancjalne z ludzkim bytem i wyprzedza jako bardziej pierwotne rozum dyskursywny i mowę. Symbol potrafi odsłonić pewne aspekty rzeczywistości - i to aspekty najgłębsze, które opierają się wszelkim innym środkom poznania. Myślenie symboliczne wymaga wyobraźni, i to wyobraźni twórczej, jak góra czy rzeka wymagają krajobrazu. Mieć wyobraźnię - to znaczy widzieć cały świat $w$ jego pełni, sięgającej w głąb bytu, gdyż moc i zadanie obrazów polega szczególnie na tym, by ukazywać to wszystko, co wymyka się zwykłej konceptualizacji12.

Podkreślając za M. Eliadem wartość symbolu, teolog uwypukla również problem zdegradowanych hierofanii i obrazów, czy też wymarłych lub na wpół zapomnianych mitów, twierdząc, że mity te, przechowywane $w$ wyobraźni, stanowią potencjalne punkty wyjścia do

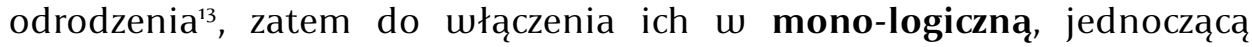
perspektywę sensu, nadbudowywanego nad sferą fragmentarycznych, izolowanych znaczeń, błędnie ograniczanych wyłącznie do partykularnych, etnicznych doświadczeń. Rozważając problem znaku, obrazu i symbolu, R. E. Rogowski zakłada zgodnie z tradycją hermeneutyczną, iż pod rzeczywistością fizyczną skrywa się rzeczywistość metafizyczna; znak (to mysterion, sacramentum), oznaczając rzecz materialną, uobecniającą rzeczywistość duchową, krystalizuje się w obrazie (he eikon) i symbolu:

Obrazy rzeczowe są wzięte ze świata rzeczy stworzonych i spełniają rolę znaku lub symbolu, które albo uobecniają Boga, albo wskazują na Niego lub na Jego przymiot. Obrazy rzeczowe mogą mieć charakter zarówno wizualny, jak i foniczny ${ }^{14}$.

Równocześnie przestrzega R. E. Rogowski przed upraszczaniem rzeczywistości (ta physika), polegającym na mitologicznej w swej genezie

"Tamże, s. 337.

${ }^{12}$ R. E. Rogowski, Wicher i myśl..., s. 15.

${ }^{13}$ Tamże.

${ }^{14}$ R. E. Rogowski, Tarasy światła..., s. 49; a także w: tenże, Mistyka gór..., s. 35-36. 
identyfikacji jej składników ze sferą metafizyczną (ta metaphysika): „Mówiąc o górach jako obrazie i znaku Transcendencji, nie twierdzimy, że góry są tą Transcendencją. One są tylko jej obrazem i znakiem"15.

\section{Podróż przez świat i jej reprezentacja w teologicznych reportażach}

Miłość musi się karmić dotykiem.

R. E. Rogowski ${ }^{16}$

Piszę jedynie o tym, co przeżyłem, czego doświadczyłem i gdzie byłem. Jeżeli piszę o Himalajach, to w Himalajach byłem. Jeśli piszę o cierpieniu i łzach, to dlatego, że cierpiałem i płakałem. Jeżeli piszę o radości, to dlatego, że się radowałem ${ }^{17}$.

Podróż przez świat zaświadcza R. E. Rogowski swoją biografią i sposobem jej odzwierciedlenia $w$ tekstach, również na poziomie podstawowej, nacechowanej symbolicznie leksyki (góra, skała, kamień, pustynia, piasek, jezioro, las, morze, ocean, niebo, chmury, deszcz, burza, obłoki, ptaki, słońce, światło, wschód słońca i zmierzch, wiatr, noc, gwiazdy, dzień, ogień, woda, powietrze, ziemia, drzewo, namiot, świeca, chleb, herbata) - stanowiącej swoisty, wewnętrzny i uporządkowany doświadczeniem słownik autora. Przyjmując dla swych autobiograficznych zapisów formę gatunkową teologicznego reportażu ${ }^{18}$, autor Misty-

${ }^{15}$ R. E. Rogowski, Mistyka gór..., s. 37. Autor podejmuje ten problem także w analizie „misterium ikony”, dookreślając owo misterium pojęciami „świata jako ikony” oraz „ikoniczności świata”, w: tenże, Ogień i słowo..., s. 428-437.

${ }^{16}$ R. E. Rogowski, Pielgrzymi morza..., s. 58. I to samo nieco inaczej: „Wolę realną kroplę wody niż całe morze wydumane, wirtualne" (R. E. Rogowski, Niewidomy spod Jerycha..., S. 19).

${ }^{17}$ R. E. Rogowski, Zamieniłeś $w$ taniec..., s. 346.

${ }^{18}$ Terminem tym posłużył się R. E. Rogowski we Wstępie do Bóg na moich drogach (s. 6), stwierdzając, iż zawarte $w$ tej książce rozdziały (drukowane pierwotnie jako odrębne teksty w czasopismach) to właśnie „reportaże teologiczne”. Ta forma gatunkowa jest dominantą lub składnikiem wypowiedzi we wszystkich niemal jego książkach. Podobną formą gatunkową, kształtowaną także jako zapis bezpośrednich doświadczeń himalaisty, posłużył się P. Matthiessen w książce Śnieżna pantera (tłum. B. Kaczorowska, Warszawa 1988), poświęconej głównie Milarepie, a stanowiącej $w$ warstwie odniesień i refleksji dyskurs religijny obejmujący tradycję biblijną i buddyjską. 
ki gór stosuje konsekwentnie zasadę przechodzenia od metonimicznej przyległości opisu do jego metaforycznego i symbolicznego znaczenia. Zabieg ten - przepisywania metonimii na metaforę i symbol - nie jest jednak zwykłym chwytem retorycznym. W jego genezie tkwi zawsze inspiracja wywodząca się z konkretnego przeżycia, a jego celem jest ponowne zanurzenie metafory czy symbolu w codziennej egzystencji, a często także w sytuacjach granicznych:

[...] kiedy wiążesz się jedną liną z drugim, bierzesz do rąk czekan i powoli wspinasz się śnieżnym stokiem Gumaczy lub lodową ścianą Dent Blanche, to lina przestaje być tylko splotem syntetycznych włókien - jest czymś więcej i czymś jeszcze innym. Jest przyjaźnią i solidarnością, na śmierć i życie ${ }^{19}$.

Owa „mistyka linowego zespołu”2o, świadomość „czegoś więcej” i „czegoś innego", skrytego pod osłoną rzeczy czy słów, sprawia, że następuje stała zmiana perspektywy widzenia wszelkich składników sfery przedmiotowej i zdarzeniowej $w$ postrzeganym świecie. Są one odczytywane i zapisywane jako ślady obecności Boga, którym pielgrzym daje świadectwo, nie tylko za pośrednictwem tego, co opowiedziane, ale także (a może przede wszystkim) poprzez zmianę stylu reakcji i egzystencji ${ }^{21}$.

Każde stworzenie na świecie może być znakiem Jego obecności i Jego działania wśród ludzi, w człowieku. Tym znakiem może być nie tylko - jak powiada Księga - gołębica, wiatr i ogień, ale może być wszystko, co istnieje, co widzą nasze oczy i czego dotykają nasze dłonie: człowiek i kwiaty, sarny i jaskółki, gwiazdy i drzewa, góry i łąki ${ }^{22}$.

W zasięgu postawy uważności świadka znajdują się również pozornie nieistotne fragmenty codzienności - przypadkowe rozmowy, telefony, spotkania, wydarzenia społeczne, także polityczne ${ }^{23}$. Choć decydującą inspirację dla życia w podróży czerpie R. E. Rogowski z natury, to jednak proponuje również fascynujący i oryginalny symbol miasta, jako przestrzeni religijnego przeżycia. Przykładem może być tutaj zapis dotyczący podróży po Hiszpanii:

${ }^{19}$ R. E. Rogowski, Mistyka gór..., s. 147.

${ }^{20}$ Tamże, s. 149.

${ }^{21}$ „Gdy wrócisz z gór, świat nadal będzie taki sam, ale ty będziesz inny” (R. E. Rogowski, Być w sercu świata..., s. 5).

${ }^{22}$ R. E. Rogowski, Pielgrzymi morza..., s. 72.

${ }^{23}$ Zob. np. R. E. Rogowski, Wicher i myśl...; Zamieniłeś $w$ taniec... 
Liturgia miasta jest liturgią, która skupia wszystko, co wyszło z rąk człowieka. W tym wypadku z rąk ludzi, którzy na przestrzeni historii zamieszkiwali Półwysep Iberyjski, a więc począwszy od Iberów i Celtów poprzez Fenicjan, Greków i Kartagińczyków, a skończywszy na Arabach i Berberach, a dzisiaj na Katalończykach, Baskach Kastylijczykach i wielu innych, czyli na Hiszpanach $[\ldots]^{24}$.

Aspekt synchronizacji zdarzeń, miejsc, czasów, treści kultury wyrażający upodmiotowienie osi diachronii, uzasadnia teolog kluczowym toposem drogi w jej zawsze aktualizującej się totalności doświadczenia. Jedną z wielkich pokus współczesnego człowieka, którym przeciustawia się autor Tarasów światła, jest pokusa totalnej historyzacji i geotypizacji doświadczeńn ${ }^{25}$, odraczająca obecność Boga jako sygnatury zdarzeń minionych. W projekcie R. E. Rogowskiego sygnatura ta nie ma $w$ ogóle aspektu czasowego $w$ sensie przemijalności, jej cechą jest trwanie ${ }^{26}$. Cywilizacja, natura, kultura i religia tworzą wspólnie Oikos dom, o którym wiedza i nauka ${ }^{27}$ (rozwijana przez teologa $w$ dziedzinie teoekologii), jako ekologia integralna, obejmując środowisko przyrodnicze, społeczne, gospodarcze, religijne i kulturowe zakłada wspólny dom dla człowieka i Boga $^{28}$, w nim zaś kształtuje postawę współbycia: być razem to współodczuwać, stawać $w$ obronie i współdziałać ${ }^{29}$. Ponawiana przez R. E. Rogowskiego krytyka kultu własności, wolności bez ograniczeń i skazywania na samotność znajduje swój przejmujący kontekst $w$ odwołaniu do Bahmana Ghobadiego, twórcy irańskiego filmu poświęconego kurdyjskim dzieciom, które „żyją bez nadziei, w skrajnym ubóstwie. Biorą udział w przemycie pośród gór i podobnie jak konie są pojone alkoholem, by nie czuły zimna i zbliżającej się śmierci"3o. Odwołanie to można, jak mi się wydaje, odczytywać szerzej, jako metaforę wielu współczesnych zjawisk społecznych.

${ }^{24}$ R. E. Rogowski, Bóg na moich drogach..., s. 265. I jeszcze inny wymiar liturgii miasta, związany z teologią codzienności zob. w: te nże, Spostrzegać Go pośród miasta...

${ }^{25}$ Por. R. E. Rogowski, Tarasy światła..., s. 74.

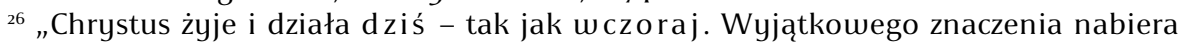
postawa Chrystusa, który mówi o sobie: »Dziś, jutro i pojutrze muszę być $w$ drodze« (Łk. 13, 33)" (R. E. Rogowski, Tarasy światła..., s. 247).

${ }^{27}$ R. E. Rogowski, Piszac na piasku..., s. 65-67.

${ }^{28}$ Ów wspólny dom dookreśla także R. E. Rogowski pojęciem synergii, odnosząc je do wszelkich sfer życia publicznego, od ekonomicznej po mistyczną; synergizm, jako współdziałanie wszystkich rozpoznań i czynów, „jest dzieckiem Agape i Miłości” (zob. R. E. Rogowski, Pielgrzymujac do raju..., s. 57-58). Dodatkowym aspektem tak rozumianej synergii jest założenie, iż wszechświat można pojmować jako środowisko komunikacji Bosko-ludzkiej (zob. R. E. Rogowski, Ogień i słowo..., s. 198 i n.).

${ }^{29}$ R. E. Rogowski, Szukając tego..., s. 180.

${ }^{30}$ R. E. Rogowski, Być w sercu świata..., s. 14. 


\section{Reductio ad misterium}

Zwijam jak tkacz moje życie. On mnie odcina od nici

Iz $38,12^{31}$

Projektowana przez R. E. Rogowskiego zasada życia w drodze, skupiającego bogactwo przeżyć, kumulującego rozległą wiedzę z dziedziny kultury, cywilizacji, antropologii nie ustanawia wartości samej w sobie. Przeciwnie - umożliwia zdobycie niezbędnego bagażu, ale tylko bagażu, który $w$ pewnym momencie wędrowiec porzuca. „W góry bierze się tylko to, co jest absolutnie konieczne, wszystko inne zostawia się na

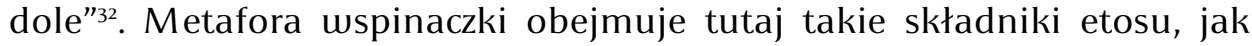
przyjęcie postawy ubóstwa, samotności ${ }^{33}$ i uniżenia (tapeinosis); wybór tych postaw, intensyfikujących świadomośćc ${ }^{34}$, oznacza zgodę i poleganie na Tym, który odcina nici. Kresem uspinającej się świadomości jest tajemnica Boga Ukrytego, rozpoznawanego pierwotnie przez wędrowca „za znakami, którymi jest całe stworzenie”35, a ostatecznie przeżywanego w przekonaniu o Jego skrytości w czymś, co daje się określić jedynie jako misterium. Zasada reductio ad misterium podtrzymuje tajemnicę nierozdzielności człowieka, świata i transcendencji ${ }^{36}$, a zarazem - stanowiąc nieprzedmiotowe przeżycie sacrum - zatrzymuje umysł przed wysłowieniem i pewnością rozpoznania. Podtrzymując myśl P. Claudela o świecie jako misterium („świat jest $w$ rzeczywistości jakimś tekstem mówiącym nam pokornie i radośnie o swej własnej nieobecności, ale także o wiecznej obecności Kogoś Innego - swego Stwórcy"37), R. E. Rogowski zwraca uwagę na topos eremos - miejsce pustynne, $w$ którym Bóg, pustynia i człowiek $^{38}$ odnawiają porozumienie. Ów symboliczny topos eremos to nie tyle ukonkretnione miejsce, ile zdarzenie, które może zaistnieć $w$ dowolnych okolicznościach, także na pustyni wielkomiejskiej ulicy - by się na niej znaleźć, niezbędna jest tęskno-

${ }^{31}$ Cytatem tym rozpoczyna Rogowski rozważania zatytułowane Hattin - góra medytacji i kontemplacji - góra powołania (w: R. E. Rogowski, Mistyka gór..., s. 169, 171).

${ }^{32}$ R. E. Rogowski, Niewidomy..., s. 18o. I podobnie w: tenże, Mistyka gór..., s. 190.

33 R. E. Rogowski, Ogień i słowo..., s. 65-74.

34 R. E. Rogowski, Być w sercu świata..., s. 37-51.

35 Por. R. E. Rogowski, Mistyka Tatr..., s. 9.

${ }^{36}$ R. E. Rogowski, Wicher i myśl..., s. 11.

37 R. E. Rogowski, Być w sercu..., s. 61.

${ }^{38}$ Tamże, s. 239. 
ta; ten składnik ludzkiego etosu podkreśla teolog za św. Augustynem jako warunek dążenia ku niepoznawalnemu ${ }^{39}$. Dodatkowe warunki to przeżycie piękna ${ }^{40}$, wymagające wysiłku, ascezy i miłości $\mathrm{i}^{41}$ oraz współcierpienie, oznaczające również stan bycia bliżej śmierci. Ten ostatni warunek podkreśla autor Tarasów światła dodatkowym, metaforycznym kontekstem: „»Chcesz perłę, dam ci perłopława - mówi Bóg do proszącego człowieka $w$ jednej $z$ opowieści wschodnich"42 - więc perła kształtuje się tu ostatecznie $w$ człowieku; nie zyskując swoistego, zewnętrznego znaku jest zarazem znakiem tajemnicy współcierpienia. $\mathrm{Na}$ inny aspekt wschodniej opowieści wskazuje jedno z odwołań teologa do mistyki żydowskiej: „Bóg, który jest Bogiem Ukrytym, »na Synaju odsłania nie swoją istotę, lecz swoją wolę - Torę" "43. Motyw Boga Ukrytego, znanego jedynie $w$ zwierciadle i zagadce (kontekstualizowany przez R. E. Rogowskiego za Izajaszem, św. Pawłem, Orygenesem, Victorem Hugo, Nikosem Kazantzakisem, Martinem Buberem, Paulem Claudelem ${ }^{44}$ ) łączy się tutaj z kolejnym, niezbędnym warunkiem podróży ku tajemnicy - z odroczeniem pragnień poznania tajemnicy na rzecz samego podjęcia podróży i jej realizacji. Na tej drodze odsłania się najpierw rzeczywistość, możliwa do określenia jako TOTUM ALIUD - ZUPEtNIE INNY, budzący fascynację i lęk ${ }^{45}$, której doświadczanie łączy R. E. Rogowski najczęściej z obrazem, symbolem i doświadczaniem gór, ponieważ to one uczą wierności ${ }^{46}$. Reprezentacja $w$ orthopraksis, której częścią jest doświadczenie mysterionu jako rezultatu współpracy ludzkiego rozumu z mądrością transcendentną ${ }^{47}$, wpływa także na re-wizję ujmowania czasu. Semeia ton kairon i ho kairos mou - znaki czasu i „mój czas” zaczynają współstanowić nową jakość egzystencji. Linia czasu nie jest już ani fizykalna, ani linearna $w$ sensie historycznym, ani ograniczona przez nietrwałość substancjalną rzeczy. Wszelkiej heterochronii zaprzecza tutaj - w reductio ad misterium - monochronia wyrażana jako Hemera Iesou - Dzień Jezusa ${ }^{48}$. Formułując ideę i praktykę podróży ku tajemnicy, R. E. Rogowski

${ }^{39}$ R. E. Rogowski, Mistyka Tatr..., s. 15.

40 Por. tamże, s. 123-133. „Nie, nie martw się, że nigdy nie będziesz w Himalajach i nigdy nie zobaczysz tych szczytów. TWOJA GÓRA JEST NAJPIEKKNIEJSZA" (s. 133).

${ }^{41}$ Por. tamże, s. 65, 69-70, 194.

${ }^{42}$ R. E. Rogowski, Pielgrzymi morza..., s. 83.

${ }^{43}$ R. E. Rogowski, Ogień i słowo..., s. 40.

${ }^{4}$ Tamże, s. 428.

${ }^{45}$ R. E. Rogowski, Mistyka gór..., s. 40.

${ }^{46}$ Tamże, s. 61.

${ }^{47}$ Tamże, s. 8-9.

${ }^{48}$ R. E. Rogowski, Być w sercu świata..., s. 161-174. 
podkreśla konsekwentnie funkcję mowy symbolicznej i wartość poezji: „Poezja jest siostrą teologii, dlatego współpracując razem, mogą jaśniej lub głębiej wyrazić Misterium”49. Retoryka owego „jaśniej lub głębiej”, komentowana $w$ kontekście reductio ad misterium, oznacza nie tyle praktykę ascezy słowa, ile umiejętność przełożenia substancjalności (literalności) znaków na ich antropologiczną i religijną wartość ekspresywną i znaczeniową, jak np. w przywołanym tu wcześniej obrazie liny można odczytywać symbol więzi między ludźmi, podejmującymi dramatyczne wyzwanie czy walkę o życie. Sens tak interpretowanego symbolu liny rekonstruuje teolog dodatkowo za Nikosem Kazantzakisem: „Gdyby któryś znalazł się $w$ śmiertelnym niebezpieczeństwie, niech pomyśli o drugim z taką mocą, aby wezwanie dosięgło go, gdziekolwiek by się znajdował"50. Zakładając hermeneutyczną interpretację języka, jako tę, dzięki której możemy przechodzić do słownika pierwotnych znaczeń, kształtujących zazwyczaj wypowiedź poetycką, a zarazem decydujących o stosunku do świata przedmiotowego, autor Mistyki gór podejmuje myśl Paula la Coura - „bycie poetą nie polega na pisaniu wierszy, ale na wynajdywaniu nowych sposobów życia"51. Jednym z filarów życia, ku którym poezja podprowadza, a który stanowi fundament etosu pielgrzyma, realizującego cel reductio ad misterium, jest medytacja. Zachowanie medytacyjne, prowadzące do jego stabilizacji jako dominującej postawy, nie powinno być „eksmitowane z życia ludzi świeckich, ludzi żyjących $w$ sercu świata" ${ }^{52}$. Z drugiej strony - nie powinno być zamykane $w$ mniszych klasztorach (także symbolicznie $-w$ klasztorach wewnętrznych) $w$ separacji od totalnie pojmowanej przestrzeni życia, bowiem wtedy „istniejesz jak studnia bez wody. I wrastasz jak drzewo o pustym pniu, które nie wydaje już żadnych owoców. I żyjesz jak ptak z przetrąconym skrzydłem. Stajesz się coraz mniej człowiekiem, a coraz bardziej cywilizowanym zwierzęciem"53. Określając medytację jako łączenie pokoju wewnętrznego z dynamicznym życiem zewnętrznym, R. E. Rogowski podkreśla jej wartość koncentrowania ludzkiej aktywności na przeżywaniu Tajemnicy; to swoiste zatrzymywanie potoku życia $w$ samym jego wirze jest jednym z kluczowych paradoksów Misterium, które autor Mistyki gór symbolizuje najprościej jednym z obrazów gór jako rąk Ziemi, wyciągniętych w geście modlitwy ku Niebu ${ }^{54}$. Przejście od medytacji do kontemplacji

\footnotetext{
${ }^{49}$ R. E. Rogowski, Ogień i słowo..., s. 109.

${ }^{50}$ R. E. Rogowski, Mistyka gór..., s. 151.

${ }^{51}$ R. E. Rogowski, Teologia i życie..., s. 10.

${ }^{52}$ R. E. Rogowski, Mistyka gór..., s. 172.

53 Tamże.

${ }^{54}$ Tamże, s. 173, 226.
} 
jest $w$ tej perspektywie przejściem ku pełni obecności, która $z$ jednej strony wyraża zrealizowaną zasadę zostaw wszystkich i wszystko, a z drugiej jest ciągłą gotowością do powrotu (i praktyką takich powrotów), ale ten, który powraca, nie jest już tym samym, który wyruszył $w$ drogę $e^{55}$. „Teologii wstępowania w górę - pisze Rogowski - uczy się człowiek nie z podręczników i nie na wykładach. Uczy się w górach i z gór"56, a tym, czego uczy się istotnie, to postawa wobec drugiego człowieka: „Bądź przyjacielem gwiazd i kwiatów, skał i morza, ale przede wszystkim bądź przyjacielem człowieka"57. Formułowany przez teologa topos drogi i wędrowca wyraża jedną $z$ najistotniejszych wartości, łączonych z pojęciem autorytetu (auctoritas); definiując to pojęcie mówimy o znaczeniu danego projektu, idei czy postawy dla danej wspólnoty. Uznawanie auctoritas to przede wszystkim uznawanie i poświadczanie pewnego dobra, proponowanego w kulturze jako cel dążeń. Zasada auctoritas w ujęciu R. E. Rogowskiego nie wiąże się $z$ narzucaniem postaw, ale ich dyskursywnym wpisywaniem $w$ sfere wątpliwości, lęków i ograniczeń; jest prośbą - sprawdź. Idź w góry.

\section{Bibliografia}

Matthiessen P., Śnieżna pantera, tłum. B. Kaczorowska, Warszawa 1988.

Niewidomy spod Jerycha zadaje pytania. Z księdzem Romanem E. Rogowskim rozmawia Barbara Juśkiewicz, Wrocław 2003.

Rogowski R. E., Bóg na moich drogach, Katowice 1986.

Rogowski R. E., Byćw sercu świata. Człowiek, teologia i góry, Wrocław 2005.

Rogowski R. E., Mistyka gór, Wrocław 1992.

Rogowski R. E., Mistyka Tatr, Kraków 2002.

Rogowski R. E., Ogień i słowo, Katowice 2005.

Rogowski R. E., Pielgrzymi morza. Medytacje morskie, Opole 1996.

Rogowski R. E., Pielgrzymując do bram raju, Opole 2003.

Rogowski R. E., Piszą na piasku, Opole 1996.

Rogowski R. E., Spostrzegać Go pośród miasta, Częstochowa 2006.

Rogowski R. E., Szukając tego, co zginęło, Opole 1996.

Rogowski R. E., Tarasy światła, Wrocław 1999.

Rogowski R. E., Wicher i myśl, Katowice 1999.

Rogowski R. E., Zamieniłeś w taniec mój żałosny lament, Opole 1999.

Teologia jako sztuka życia, red. ks. R. E. Rogowski, ks. A. Małachowski, Wrocław 2008.

Zawadzki A., Hermeneutyka śladu i hermeneutyka świadectwa, [w:] Nowoczesność jako doświadczenie, red. R. Nycz, A. Zeidler-Janiszewska, Kraków 2006.

55 „Kiedy więc wracasz z gór, z którymi jesteś w wiecznej komunii, jesteś jak ptak ze słońcem w szponach" (tamże, s. 220).

${ }^{56}$ Tamże, s. 233.

${ }^{57}$ Tamże, s. 269. 